\title{
Research on Destocking of Real Estate Industry in the Background of Supply Side Reform
}

\author{
Rui Chen \\ Yunnan College of Business Management,Anning, 650304, China
}

\begin{abstract}
Destocking of real estate is the important content of supply side reform in China. Destocking decision is the necessary choice of the new economic situation and has clear and feasible paths. This paper gives the basic directions of real estate destocking, including Improve supply of real estate enterprises, promote marketing of real estate enterprises and decrease taxes of real estate enterprises to provide some references for the relative researchers.
\end{abstract}

Keywords:destocking, real estate, supply side reform

\section{Introduction}

Since the new century, Chinese real estate with the rapid development of urbanization and commercialization of housing development, real estate development volume continued rapid growth, rising prices, the real estate market has created a great demand, become the new century China high growth huge pulling power. But with China's economy into the new normal economic slowdown, the real estate market supply and demand is also undergoing major changes. Real estate sales area cumulative growth rate decline trend, the real estate stocks continue to increase. This shows that China's real estate market as a whole is greater than the supply of effective demand. This imbalance between supply and demand in the region is growing, to resolve the real estate inventory has become one of the important tasks. Domestically, China is at the stage of adjustment and transformation of old and new kinetic energy, facing the downward pressure on the economy and industrial restructuring and upgrading. According to the theory of total demand management, mainly from the investment, consumption, export three carriages to stimulate economic growth. In 
terms of exports, with China's land prices continued to rise, as well as the continued appreciation of the exchange rate in recent years, China's export advantage gradually weakened. In terms of consumption, because of the social security system is not perfect and the residents' savings rate is high. In contrast, the stimulating effect of investment on the economy is more significant, but the rate of return on investment in China continued to decline in recent years. Therefore, the supply side reform has become the general idea of China's current economic reform. This paper intends to explore the current concern of the real estate inventory problem in the context of supply side reform.

\section{Necessity of Real Estate Destocking in the Background of Supply Side Reform}

The real estate industry as a result of the industry chain is relatively long, more surrounding industries. Therefore, the real estate industry is an important pillar of our economy for a long time. Real estate investment and construction of huge funds for the regional economic development has a positive effect, the local government is often the real estate industry as a leader in regional economic development. At the same time, the development of the real estate industry, but also for the relevant industries to provide a large number of jobs, improve the local employment rate, to enhance the income of local residents also has a positive help. Of course, with the rapid progress of China's economic and social progress, high standards of service complete and convenient peripherals have become the requirements of the real estate industry. In short, the real estate in China's economic and social development will continue to play an important role for a long time. Since the reform and opening up, the main contradiction of Chinese society is the contradiction between the growing material and cultural needs of the people and the backward social production. Since the beginning of the new century, China's exports of products have increased substantially, but the financial crisis in the past few years has led to a decrease in the demand for Chinese exports. It has caused the phenomenon that the export commodities of our country cannot be sold, resulting in serious surplus. At the same time, there are many industries in the low-end products. Many industries need to optimize the supply structure. The real estate industry as an important pillar of China's economy, but also the emergence of the industrial structure of the problem, and now China's property market is the most important problem of excess inventory.

\section{Feasibility of Real Estate Destocking in the Background of Supply Side Reform}

At present, there are two popular ways to inventory. We should reform the household registration system to deepen the reform of the system as the core to accelerate the migrant workers. However, the implementation of this approach needs to consider a number of factors. On the one hand, a lot of relatively high income farmers tend to work in developed cities. They prefer to buy in developed 
cities, and the need to increase the stock of the vast number of underdeveloped cities. On the other hand, many migrant workers do have real needs, but more is the potential demand for the purchase, because the purchasing power has been purchased, and the potential demand of migrant workers in the face of high prices is difficult to have the ability to pay, even if the government subsidies, as they have a certain job the instability of the mortgage will also have a certain degree of risk. And in order to speed up the implementation of the real estate inventory for migrant workers rapid urbanization. This is bound to bring higher social security needs than the rural population. The lack of land revenue has been a serious challenge to local finance. The second comparison is to open up the path of government procurement. This is a way to get through the government's affordable housing market and commercial housing market channels. It includes the government to provide housing reform resettlement housing, public rental and leasing, etc. by way of monetary resettlement, given by the government to enjoy the protection of one-time monetary subsidies to residents, residents to purchase their own commercial housing. This is one of the most realistic and most ideal way to inventory, but also by the government to negotiate with the developers, not only conducive to speed up inventory, but also conducive to reduce prices, more government repeated construction waste of resources.

\section{Directions of Real Estate Destocking in the Background of Supply Side Reform}

\subsection{Improve supply of real estate enterprises}

Real estate inventory, not only to reduce the supply of real estate inventory, but based on the real needs of the market, to create effective supply. Through the support of the real estate enterprises to adapt to market demand, adjust product structure, the real estate production factors leading to the development of the field. For example, take a number of policies to support the transformation of enterprises to tourism real estate, pension real estate, sports real estate, etc.. For projects under construction, help enterprise financing, accelerate the construction progress, reduce the project unfinished, to prevent the risk of default. The introduction of high-quality real estate enterprises, mergers and acquisitions to encourage mergers and acquisitions, reduce resource losses and waste. It should be clear that the real estate supply side reform is the key to a series of structural adjustment to stimulate the vitality of market players. Therefore, the traditional real estate enterprises should try to enhance their innovation capability, actively use the Internet and other information technology, starting from the needs of users, to the real estate product design, sales and financing mode should actively learn from the Internet thinking, and can effectively use the cloud computing technology and advanced information technology, strengthen the research of demand for real estate and real estate positioning for users, the real estate market innovation to improve the supply capacity, open and transparent operation to achieve the supply of real estate. Real estate enterprises should effectively reduce the inventory of real estate, and make a positive contribution to the subsequent 
development of real estate. Real estate enterprises only the advantages of the Internet in real estate enterprises fully unfolded, gradually realize the organic combination of Internet, real estate and finance, can make the enterprise in an invincible position in the fierce competition in the business.

\subsection{Promote marketing of real estate enterprises}

The idea of innovation is the foundation of an enterprise's continuous development. It can promote the improvement of enterprise organization form and management efficiency, so as to improve the efficiency of enterprises, so as to adapt to the requirements of economic development. In essence, marketing innovation is a means to improve the competitive advantage of projects. With the rapid development of the times, some of the traditional theory of real estate marketing will not meet the requirements of the market. Small and medium-sized city part with city development characteristics, accelerate the upgrading of industrial structure, make the city comprehensive competitive strength can be improved, improve the quality of life in the city, in order to attract foreign population, to keep the dynamic balance of supply and demand of housing. With the acceleration of urbanization in China, more and more farmers choose to migrate from rural to urban areas. Encourage farmers to purchase houses, help to achieve the purpose of inventory. This situation led to the practice of marketing innovation disorder, but also to increase the cost of real estate business innovation and risk, limiting the development of the real estate business. In the context of supply side reform, in the context of opportunities and challenges, the real estate market research needs major reform, innovation, in-depth investigation of the market situation, to meet the needs of the public. For the investigation of the market situation, from a macro point of view, to understand the introduction of relevant laws and regulations of real estate, finance, land, housing and other policies. From the economic point of view, the real estate enterprises to investigate the economic situation of consumers, to understand the per capita income of residents and their spending power, as well as the surrounding industrial structure. If this is not the case, the enterprise will be difficult in the competitivemarket.

\subsection{Decrease taxes of real estate enterprises}

As an important pillar industry, the real estate industry lacks of long-term government policy in the policy formulation and the guide means, often leads to the phenomenon of tax evasion, stocks continued to raise, higher risk funds frequent phenomenon. Therefore, to solve the real estate inventory problems, we should establish and perfect the relevant industry policies and regulations, should have control means in the short term, also need long-term policy laws and regulations, to form a reasonable length, flexible specification of effective systems; we should strengthen the industry approval efforts and supervision measures, for without qualification enterprise resolutely stop, severely punished for illegal business enterprises, and strive to create a harmonious and healthy real estate market; not high prices in China, an important reason is the high taxes. 
This layer for countries to actively study the relevant tax issues, through tax exemption and tax means to effectively reduce the real estate enterprise tax pressure, effectively reducing China's high prices, so that people can buy a house. The real estate industry has many characteristics, such as taxes, tax burden and tax risk. The real estate industry once again become a mandatory inspection program, the real estate industry has been listed as a special inspection of the annual industry, the real estate enterprise tax risk high remarkable. In the face of higher tax risk, how to reduce the tax burden and effectively control the tax risk has become the most important research topic of the real estate enterprises. In order to effectively control the tax risk, real estate enterprises should combine their own business situation, the establishment of the corresponding tax risk management system.

\section{Conclusion}

The current situation of high inventory of real estate has seriously affected the healthy development of China's real estate market. In the background of China's supply side reform, this paper points out the necessity and feasibility of the destocking of China's real estate. This paper also analyses the directions of destocking of the real estatein order to promote the healthy and orderly development of the real estate market.

\section{References}

[1]Wang Guan, JiYusheng, On Real Estate De-stocking in Supply Side Reform, Value Engineering, 25(13), pp. 61-63, 2016.

[2]Xiang Weimin, Wang Shuang, De-inventory of Real Estate and the Corresponding Orientation, Reform, 29(6), pp. 111-119, 2016.

[3]Shen Bo, the Influence of Real Estate Industry on Regional Financial Stability in "Destocking"Perspective-An Empirical Study Based on Spatial Panel Model, Journal of Hebei University of Economics and Business, 37(3), pp. 61-66+101, 2016.

[4]ZengXiankui, Research on the Strategy of Destocking Real Estate Inventory in China, Reformation \& Strategy, 32(11), pp. 59-62, 2016. 